\title{
26. SHALLOW-WATER FORAMINIFERAL TAPHOCOENOSES AT SITE 821: IMPLICATIONS FOR THE PLEISTOCENE EVOLUTION OF THE CENTRAL GREAT BARRIER REEF SHELF, NORTHEASTERN AUSTRALIA ${ }^{1}$
}

\author{
Lucien F. Montaggioni ${ }^{2}$ and Marie-Thérèse Vénec-Peyré 3
}

\begin{abstract}
Reworked shallow-water foraminifers that settled on the upper slope of the central Great Barrier Reef at Site 821 (water depth, $212.6 \mathrm{~m}$ ) were used as indicators of the paleoclimatic and paleoenvironmental conditions that have controlled the Pleistocene evolution of the adjacent platform. Throughout the 400-m-thick sequence drilled, the nature, composition, and distribution of the shallow-water foraminiferal assemblages studied indicate that (1) all the species recorded are at present living in diverse tropical, reef-related areas of the Indo-Pacific and Atlantic provinces; (2) the composition of the microfaunal taphocoenoses is almost identical between the different stratigraphic intervals studied and the modern Great Barrier Reef environments; (3) inner-neritic, tropical environments have continued to develop since the middle Pleistocene; (4) high- to moderate-energy platform edges occurred repeatedly throughout Pleistocene time. These factors may suggest that, since the beginning of the Pleistocene, several reef-like tracts have grown successively on the central area of the northeastern Australian shelf edge. These tracts probably had a sufficiently evolved morphological zonation to act as shelters for foraminiferal biocoenoses of high species diversity.
\end{abstract}

\section{INTRODUCTION}

One of the main objectives of Leg 133 of the Ocean Drilling Program, during which the carbonate platforms of northeastern Australia were drilled, was to determine the timing and factors controlling the development of the central region of the Great Barrier Reef (GBR). For years, much attention has been devoted to defining the nature, geometry, and age of the modern reefs and subreef deposits. Most work in the region has been largely geophysical (Davies et al., 1987; Symonds et al., 1983; Feary et al., 1991) and has shown that, on the outer continental shelf of the central GBR, 250- to 300-m-thick reef complexes occur in the form of a series of reef bodies separated by low-sea-level-generated unconformities. The reef complex constitutes only the uppermost part of a thick sequence that has been dominated by fluviodeltaic sediments. In addition, a borehole drilled in 1926 at Michaelmas Cay, off Cairns, shows about $100 \mathrm{~m}$ of presumably Pliocene-Pleistocene reef facies overlying siliciclastic sediments (Lloyd, 1973). Davies et al. (1987, 1989) showed that the GBR was diachronous in its development (i.e., Miocene in the north and Pliocene-Pleistocene in the south). In the central region, the reef system that developed upon progradational fluvioclastic packages must be a young feature. Reef growth was thought to have begun in the late Pliocene to Pleistocene or later. Preliminary results obtained from shipboard investigations suggested a very young age for the central GBR area (less than $1 \mathrm{Ma}$ ). Moreover, the modern GBR environments and surface sediments are well documented, mainly from the central region (Maxwell, 1968; Scoffin and Tudhope, 1985; Tudhope and Scoffin, 1988).

Based on the biosedimentological analysis of Site 821, this chapter is a contribution to elucidate the geological evolution of the central GBR region and, more particularly, the platform growth history. Basically, close inspection of platform-derived organisms deposited onto the upper slope of the GBR would provide relevant information about possible reef occurrences. However, detritus resulting from disintegration of typical reef-dwelling organisms (i.e., scleractinian

\footnotetext{
'McKenzie, J.A., Davies, P.J., Palmer-Julson, A., et al., 1993. Proc. ODP, Sci. Results, 133: College Station, TX (Ocean Drilling Program).

${ }^{2}$ URA-CNRS 1208, Université de Provence, 13331 Marseille cedex 3, France.

${ }^{3}$ URA-CNRS 12, Institut de Paléontologie, Muséum National d'Histoire Naturelle, 75005, Paris, France.
}

corals, various calcareous algal species, and mollusks, etc.) lose diagnostic characteristics when reaching the pebble $(6 \mathrm{~mm})$ to very coarse sand (1-2 mm) size ranges. Given that the mean sizes of the sediments at Site 821 are generally smaller than $0.15 \mathrm{~mm}$, confusion with fragments produced by deeper- or colder-water organisms (i.e., ahermatypic corals, calcareous algae, mollusks, etc.) is highly possible. Moreover, the original platform-generated signal was disturbed by post-mortem displacement of bioclasts, because only a minor part of the reef-derived detritus reaches the fore-reef aprons (Davies, McKenzie, Palmer-Julson, et al., 1991). Foraminifers remain the only identifiable taxa on species or genera levels, even in the fine sand size; therefore, they have been selected to be used as paleobathymetric and paleoclimatologic markers.

\section{MATERIAL AND METHODS}

Site 821 is one of three sites (with Sites 819 and 820 ) located on the upper slope of the Great Barrier Reef system and in the most proximal position with respect to the latter, at $16^{\circ} 38.793^{\prime} \mathrm{S}$ and $146^{\circ} 17.376^{\prime} \mathrm{E}$ (Fig. 1). Water depth is $212.6 \mathrm{~m}$ below sea level. Hydraulic piston coring was continuous from 0.0 to $145.9 \mathrm{~m}$ below seafloor (mbsf) (Cores $133-821 \mathrm{~A}-1 \mathrm{H}$ to $-16 \mathrm{H}$ ), with $102.4 \%$ recovery. The extended core barrel system was used from Cores 133-821A$17 \mathrm{X}$ to $-43 \mathrm{X}$, reaching $400 \mathrm{mbsf}$, with $91.88 \%$ recovery.

The series to $400 \mathrm{mbsf}$ is an expanded Pleistocene sequence; nannofossils indicate that the bottom of Hole 821A has an age of 1.27 to $1.48 \mathrm{Ma}$. (Davies, McKenzie, Palmer-Julson, et al., 1991). Lithostratigraphy was divided into five units, based on sharp facies changes, that displayed alternations between siliciclastic-rich, terrestrial and carbonate-rich, marine skeletal sediments (Fig. 2). Lithologic evidence suggests an unconformity between lithologic Units II and I.

The material investigated comes from Cores 133-821A-43X through $-1 \mathrm{H}$, by collecting one $10 \mathrm{~cm}^{3}$ sample from each section. In the shore-based laboratory, the samples were dried at $60^{\circ} \mathrm{C}$ and then weighed before being washed through a series of sieves having mesh sizes of 500,150 , and $125 \mu \mathrm{m}$, respectively. A total of 271 samples was qualitatively examined to retrieve information about the richness of the benthic microfauna and the preservational state of the shells. Throughout the hole, rich and well-preserved assemblages appear to alternate with poorly diversified and preserved ones. The samples containing the richest and best-preserved taphocoenoses are the fol- 
lowing, from base to top: $133-821 \mathrm{~A}-38 \mathrm{X}-5,30-32 \mathrm{~cm}$; $133-821 \mathrm{~A}-$ $35 \mathrm{X}-1,30-32 \mathrm{~cm}$; all samples from Core 133-821A-34X. Sections 133-821A-24X-1, -24X-2, -23X-3, -22X-1, -17X-3, -15H-7, -11H-4 to $-11 \mathrm{H}-1,-2 \mathrm{H}-2,-2 \mathrm{H}-3$, and Core $133-821 \mathrm{~A}-1 \mathrm{H}$. The taphocoenoses from Core $133-821 \mathrm{~A}-18 \mathrm{X}$ are relatively poor and severely altered as are those from Sections 133-821A-17X-6 to -17X-4.

Three types of analysis were performed to assess the benthic foraminiferal content. First, qualitative analysis of the benthic microfauna restricted to the neritic zone was performed for the fraction larger than $125 \mu \mathrm{m}$ on seven samples regarded as accurately representative of foraminiferal assemblages through Pleistocene time in the region considered. The intervals studied were as follows: $133-821 \mathrm{~A}-1 \mathrm{H}-1$, $30-32 \mathrm{~cm}$ (0.30 mbsf); 133-821A-11H-1, 30-32 cm (90.20 mbsf); 133-821A-17X-3, 30-32 cm (149.20 mbsf); 133-821A- 24X-1, 131$133 \mathrm{~cm}$ (214.10 mbsf); 133-821 A-35X-1, 30-32 cm (219.30 mbsf); 133-821A-42X-1, 21-23 cm (386.59 mbsf) and 133-821 A-43X-3, $30-32 \mathrm{~cm}$ (399.40 mbsf). Second, semiquantitative estimates of the abundance of larger foraminifers were done for the whole 271 samples in the fraction coarser than $500 \mu \mathrm{m}$, because most are considered to be symbiont-bearing forms (i.e., platform-dwelling foraminifers; Leutenegger, 1984). Finally, three representative samples (133-821 A-1H$1,30-32 \mathrm{~cm} ; 133-821 \mathrm{~A}-17 \mathrm{X}-3,30-32 \mathrm{~cm} ; 133-821 \mathrm{~A}-35 \mathrm{X}-1,30-32$ $\mathrm{cm}$ ) were selected for quantitative analysis of the total benthic foraminiferal content, with each count including 200 to 300 individuals.

As a taxonomic framework, the foraminiferal classification proposed by Loeblich and Tappan (1974) has been adopted here.

\section{STRATIGRAPHIC DISTRIBUTION OF THE SHALLOW-WATER FORAMINIFERAL ASSEMBLAGES}

Inspection of the sediment fractions coarser than $500 \mu \mathrm{m}$ throughout the cores reveals the distributional pattern of larger foraminifers as detritus. Amphisteginids are relatively scarce in the lower part of the hole, below Core 133-821A-30X (280 mbsf). These occur commonly within Sections 133-521A-18X-4, 22X-1, 27X-4 and 29X-1. Their amount increases in the upper part of the hole, in Sections 133-821A$16 \mathrm{H}-4,-14 \mathrm{H}-1,-13 \mathrm{H}-7$ to $-13 \mathrm{H}-3,-12 \mathrm{H}-6,-11 \mathrm{H}-4,-11 \mathrm{H}-2,-11 \mathrm{H}-1$, $-10 \mathrm{H}-7,-8 \mathrm{H}-5,-8 \mathrm{H}-3,-7 \mathrm{H}-2,-5 \mathrm{H}-4,-5 \mathrm{H}-3,-5 \mathrm{H}-1,-3 \mathrm{H}-3,-2 \mathrm{H}-5$ and, $-2 \mathrm{H}-4$. The most common form belongs to the species Amphistegina papillosa. Fragments of heterosteginid tests (Heterostegina $\mathrm{cf}$. depressa) are markedly less common; these were encountered in Sections 133-821A-2H-1, -2H-4, -5H-3, -10H-7, -11H-1 and -24X-1. Pieces of Operculina cf. ammonoides seem to be restricted in Sections 133$821 \mathrm{~A}-2 \mathrm{H}-5,-4 \mathrm{H}-4,-5 \mathrm{H}-3,-5 \mathrm{H}-4,-7 \mathrm{H}-3,-8 \mathrm{H}-5,-11 \mathrm{H}-2,-24 \mathrm{X}-1$, $-29 \mathrm{X}-1$, and $-35 \mathrm{X}-1$. The species Alveolinella quoyi was recorded to Sections $133-821 \mathrm{~A}-2 \mathrm{H}-4,-5 \mathrm{H}-4$ and, $-11 \mathrm{H}-1$ only. By way of contrast, the anomalinids Heterolepa praecincta and $H$. margaritifera as well as the rotaliid Asterorotalia gaimardii are widespread. As a whole, larger foraminifers tend to decrease markedly in amount downhole, below Section 133-821A-16H-4. However, this is not of general value. Indeed, within the upper part of the hole, these larger foraminifers are absent in numerous sections, particularly in Core $133-821 \mathrm{~A}-1 \mathrm{H}$. This suggests that the dearth of symbiont-bearing foraminifers in the sediments deposited along the outer margin does not indicate drastic environmental changes on the adjacent platform. Moreover, when present, these organisms are not more abundant in the upper one-half of the hole than in the lower part and rarely exceed $5 \%$ of the whole foraminiferal population.

Table 1 gives the list of shallow-water foraminifers present within the sediment fractions coarser than $125 \mu \mathrm{m}$, in the seven intervals selected from Sections 133-821A-1H-1, $-11 \mathrm{H}-1,-17 \mathrm{X}-3,-24 \mathrm{X}-1$, $-35 \mathrm{X}-1,-42 \mathrm{X}-1$, and $-43 \mathrm{X}-3$. There were 104 species encountered, distributed as follows: suborder Textulariina ( 8 species), suborder Miliolina (29 species), and suborder Rotaliina (67 species). The species number varies between 64 and 54 , from 0.30 to $319 \mathrm{mbsf}$. The

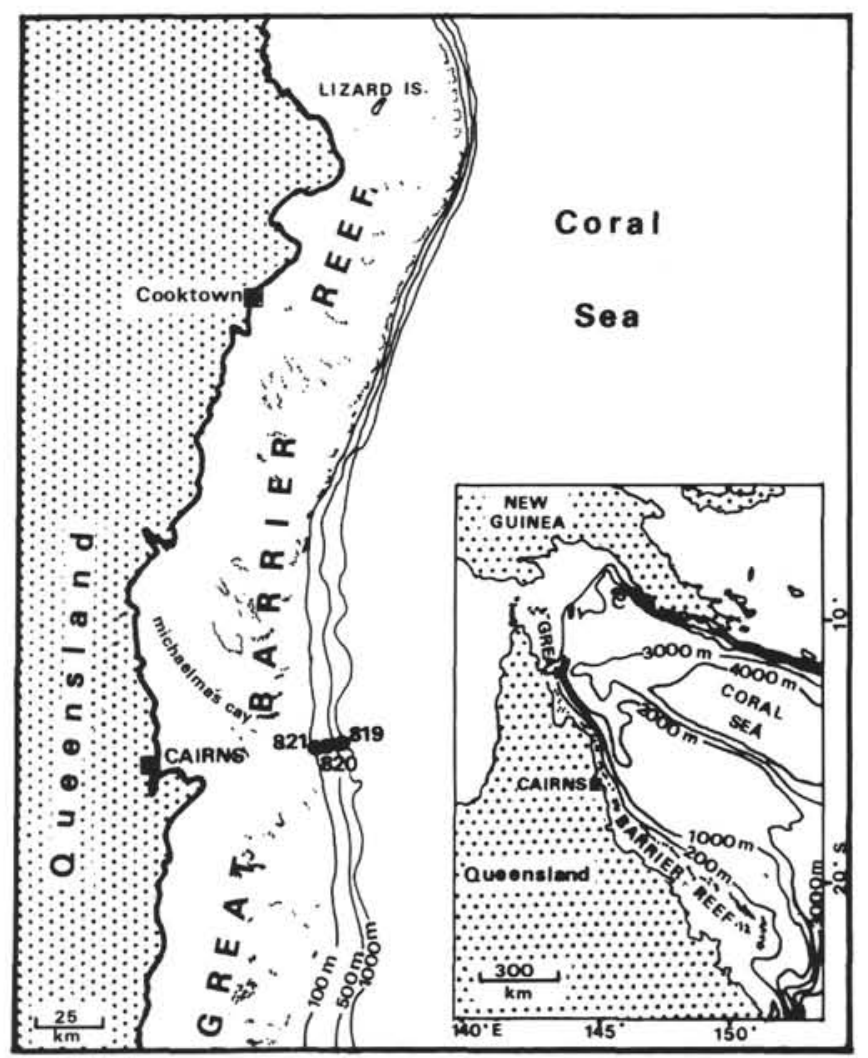

Figure 1. Map showing the situation and general physiographies of the Great Barrier Reef system of Australia (northwestern margin), with location of Sites 819,820 , and 821 .

apparent specific diversity diminishes markedly downhole, with the number of species ranging from 17 to 21 , at depths of 306.59 and 399.40 mbsf respectively. Such a decrease is probably due to poor preservation of initially deposited foraminiferal tests as a consequence of increasing-downward diagenetic alteration (Davies, McKenzie, Palmer-Julson, et al., 1991). About $75 \%$ of the species recorded at Site 821 had already been reported by Collins (1958) and Baccaert (1987) from the modern-reef environments of the northern Australian margin. The remaining percentage corresponds to forms described from other Indo-Pacific and/or Atlantic tropical reef areas (Chapman, 1900; Cushman, 1921a, 1921b; Cushman et al., 1954; Todd and Post, 1954; Graham and Militante, 1959; Todd and Low, 1960; Guilcher et al., 1965; Hirshfield et al., 1968; Brazier, 1975; Le Calvez and Salvat, 1980; Poag and Tresslar, 1981; Montaggioni, 1981; Vénec-Peyré, 1985, 1991; Montaggioni et al., 1986; Murray, 1991).

The relative percentages of the three foraminiferal suborders (Textulariina, Miliolina, and Rotaliina) in the samples studied are plotted in Figure 3, according to the method of Murray (1973). For comparison, the summary data compiled by Baccaert (1987) from the Lizard Island Reef area are plotted simultaneously. All the samples are concentrated along the Miliolina-Rotaliina side of the diagram, thereby indicating a life environment of normal marine lagoons. Our results thus appear to be consistent with Baccaert's study. At Site 821, percentages of Textulariina are generally low (less than 9\%), showing a same order of magnitude as in the Lizard reef area (less than 10\% except for some perireefal areas). The concentration of Miliolina varies from $9 \%$ to $35 \%$; these values are similar to those obtained from the Lizard back-reef zones. Concerning Rotaliina, the abundance is high ( $61 \%$ to $100 \%$ of the total benthic foraminiferal assemblage) at Site 821 as it occurs in the samples from the reef flats around Lizard Island. However, attention must be paid to the samples from 


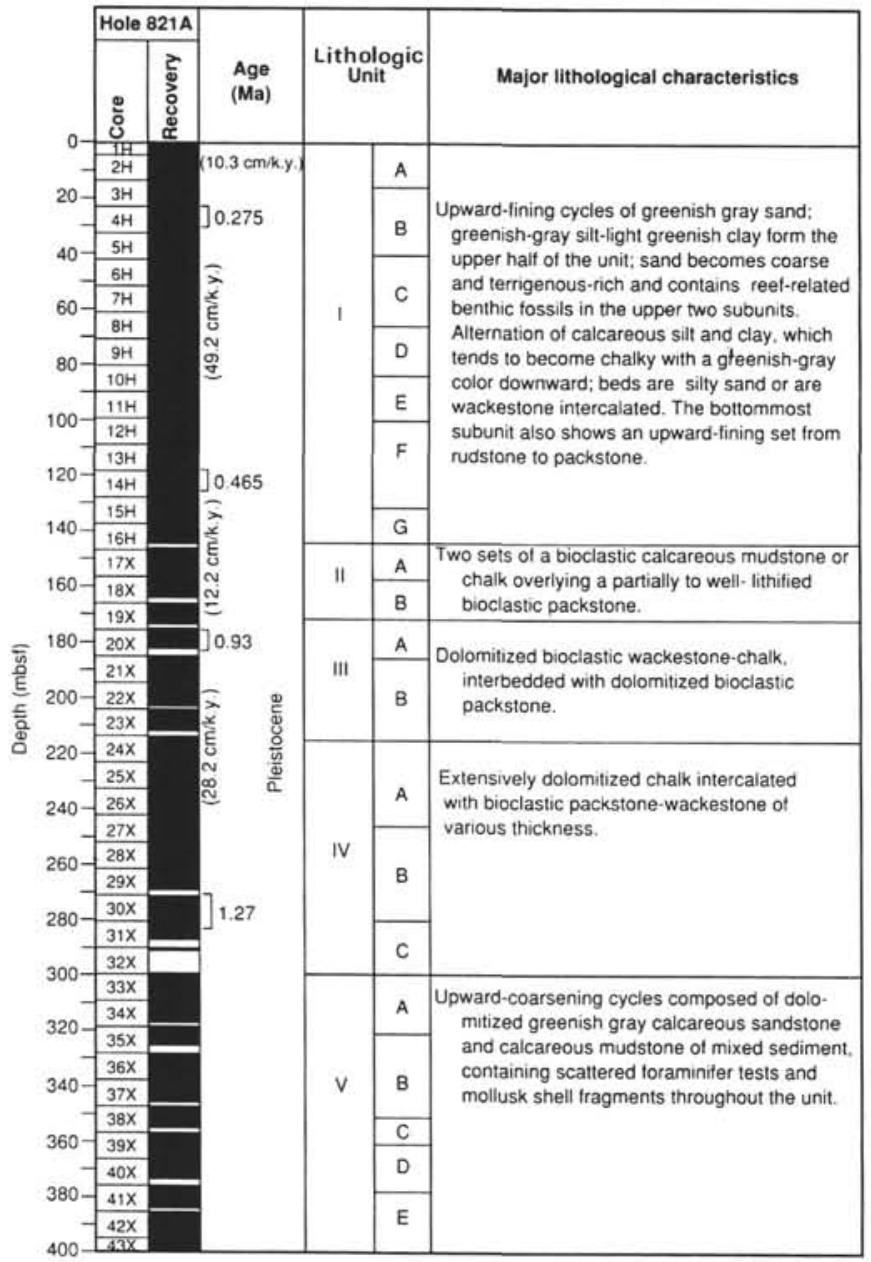

Figure 2. Summary chart indicating the lithostratigraphy and lithologic characteristics for each unit at Site 821. Age assignment provided by nannofossil biostratigraphy (from Davies, McKenzie, Palmer-Julson, et al., 1991, p. 577).

intervals $133-821 \mathrm{~A}-42 \mathrm{X}-1,21-23 \mathrm{~cm}$, and $-43 \mathrm{X}-3,30-32 \mathrm{~cm}$, that give a distorted picture of the originally deposited shallow-water foraminifers because of poor preservation.

Considering its time of deposition (about 1 k.y.), the uppermost interval taken into account here (133-821 A-H1-1, 30-32 cm) can be regarded as a reference for the distributional pattern of Holocene foraminiferal thanatocoenoses derived from the GBR platform. The species representative of the three suborders Textulariina, Miliolina, and Rotaliina are 3,20, and 38 respectively. These numbers comprise the boundary values obtained for the three suborders $(0-22,22-83$, 30-104 species, respectively) from the various reef zones in the Lizard Island area (Baccaert, 1987). The percentages of species shared by both the reference sample and the lower ones have been estimated. Among the forms present at interval $133-821 \mathrm{~A}-11 \mathrm{H}-1,30-32 \mathrm{~cm}, 54.7 \%$ are identical to those of the reference sample, 55\% at interval 133-821 A$17 \mathrm{X}-3,30-32 \mathrm{~cm}, 62 \%$ at interval $133-821 \mathrm{~A}-24 \mathrm{X}-1,131-133 \mathrm{~cm}$, $68 \%$ at interval $133-821 \mathrm{~A}-35 \mathrm{X}-1,30-32 \mathrm{~cm}, 76 \%$ at interval $133-$ $821 \mathrm{~A}-42 \mathrm{X}-1,21-33 \mathrm{~cm}$, and $80 \%$ at interval $133-821 \mathrm{~A}-43 \mathrm{X}-3,30-32$ $\mathrm{cm}$. Thus, the foraminiferal composition of the samples analyzed appears to be closely related throughout the hole.

Results of quantitative analysis of three representative assemblages on the family level are given in Table 2. For each family, only individuals belonging to species recorded from the modern innerneritic, euphotic $(0-120 \mathrm{~m})$ environments and, particularly, from reef provinces were taken into account. The percentages refer to the
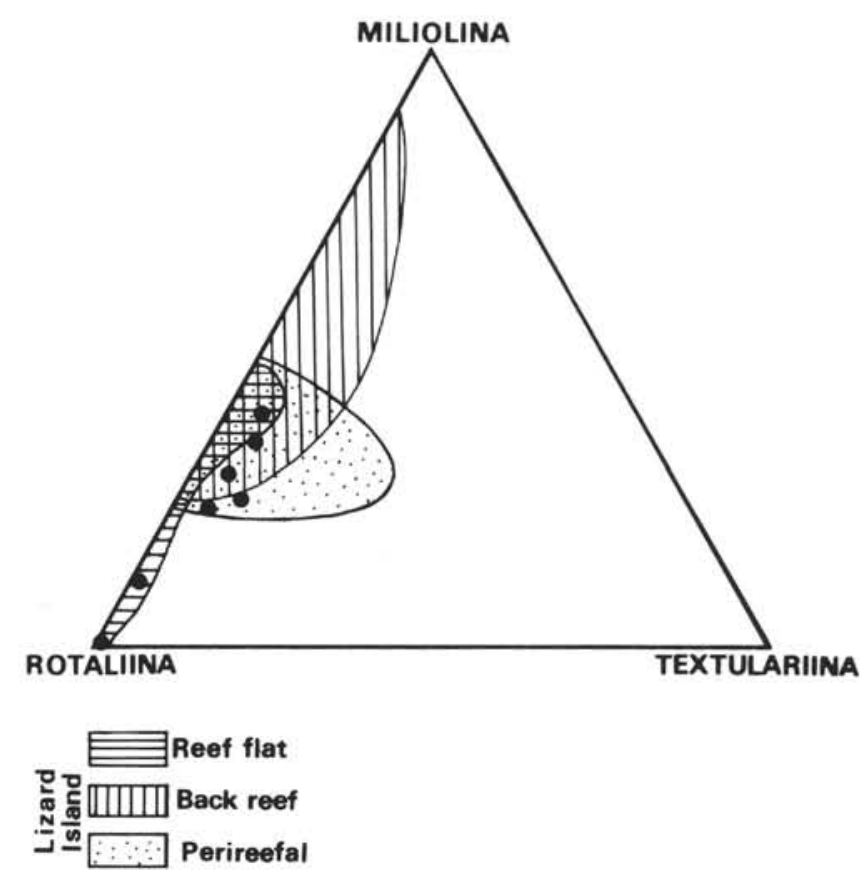

Figure 3. Triangular diagram showing the distribution of foraminiferal species in Samples 133-821A-1H-1, 30-32 cm; - 11H-1, 30-32 cm;-17X-3, 30-32 cm; $-24 \mathrm{X}-1,131-133 \mathrm{~cm} ;-35 \mathrm{X}-1,30-32 \mathrm{~cm} ;-42 \mathrm{X}-1,21-23 \mathrm{~cm}$; and $-43 \mathrm{X}-3$, $30-32 \mathrm{~cm}$, according to the method of Murray (1973). For comparison, the summary triangular plot constructed by Baccaert (1987), showing the main reef environments from Lizard Island area, is also reproduced.

abundance of these shallower individuals relative to the total benthic population (including outer-neritic and deeper microfauna). The innerneritic foraminifers largely dominate, representing $79.5 \%, 79.1 \%$, and $76.6 \%$ in Samples 133-821A-1H-1 (30-32 cm), -17X-1 (30-32 $\mathrm{cm})$ and $-35 \mathrm{X}-1(30-35 \mathrm{~cm})$, respectively. So, more than three quarters of the individuals came from the adjoining platform. Frequency is similar from sample to sample. The bulk of the assemblages is composed of individuals belonging to nine main families (Bolivinitidae, Rotaliidae, Uvigerinidae, Cymbaloporidae, Discorbidae, Miliolidae, Anomalinidae, Cibicidae, Amphisteginidae). Abundance of Bolivinitidae ranges between $4.1 \%$ and $17.8 \%$ of the total benthic foraminiferal assemblage; the most common species is Bolivina compacta $(1.9 \%-14.9 \%)$, which mainly inhabits the modern perireefal GBR areas, as epiphyte of cyanobacterial coats. Among Rotaliidae, the species Asterorotalia gaimardii predominate, reaching $15.8 \%$ of the total benthic individuals; this contrasts sharply with their dearth in the modern GBR taphocoenoses, which may be partly explained by their preferential occurrence in perireefal to off-reef shelf environments (Collins, 1958; Baccaert, 1987). Concentrations of Uvigerinidae decrease markedly from the upper to the lower samples $(18.5 \%$ to $2.2 \%$ ); Siphouvigerina ampullace $a$ and Trifarina bradyi show high frequencies in the upper sample $(14.4 \%$ to $3.8 \%$, respectively) in contrast to their scarcity in modern biocoenoses (Baccaert, 1987); this is probably caused by transporting effect rather than local environmental changes. Abundances of Cymbaloporidae vary widely ( $3.2 \%$ $10.5 \%)$; these values appear to partly reflect the relative high frequency of living individuals in the modern GBR biocoenoses. Concerning Discorbidae, the amount ranges between $3.9 \%$ and $8.3 \%$; the species Gavelinopsis lobatulus, which lives in perireefal zones, is one of the most common, averaging $2 \%$ of the total benthic population. The content of Miliolidae varies from $6.1 \%$ to $11.2 \%$. No specific form is clearly dominant: 11 to 14 species exhibit amounts varying between $0.4 \%$ and $1.9 \%$. The Quinqueloculina species present in the samples (see Table 1) are regarded as characteristic proximal back- 
Table 1. Checklist of the shallow-water foraminifers present in Hole 821A.

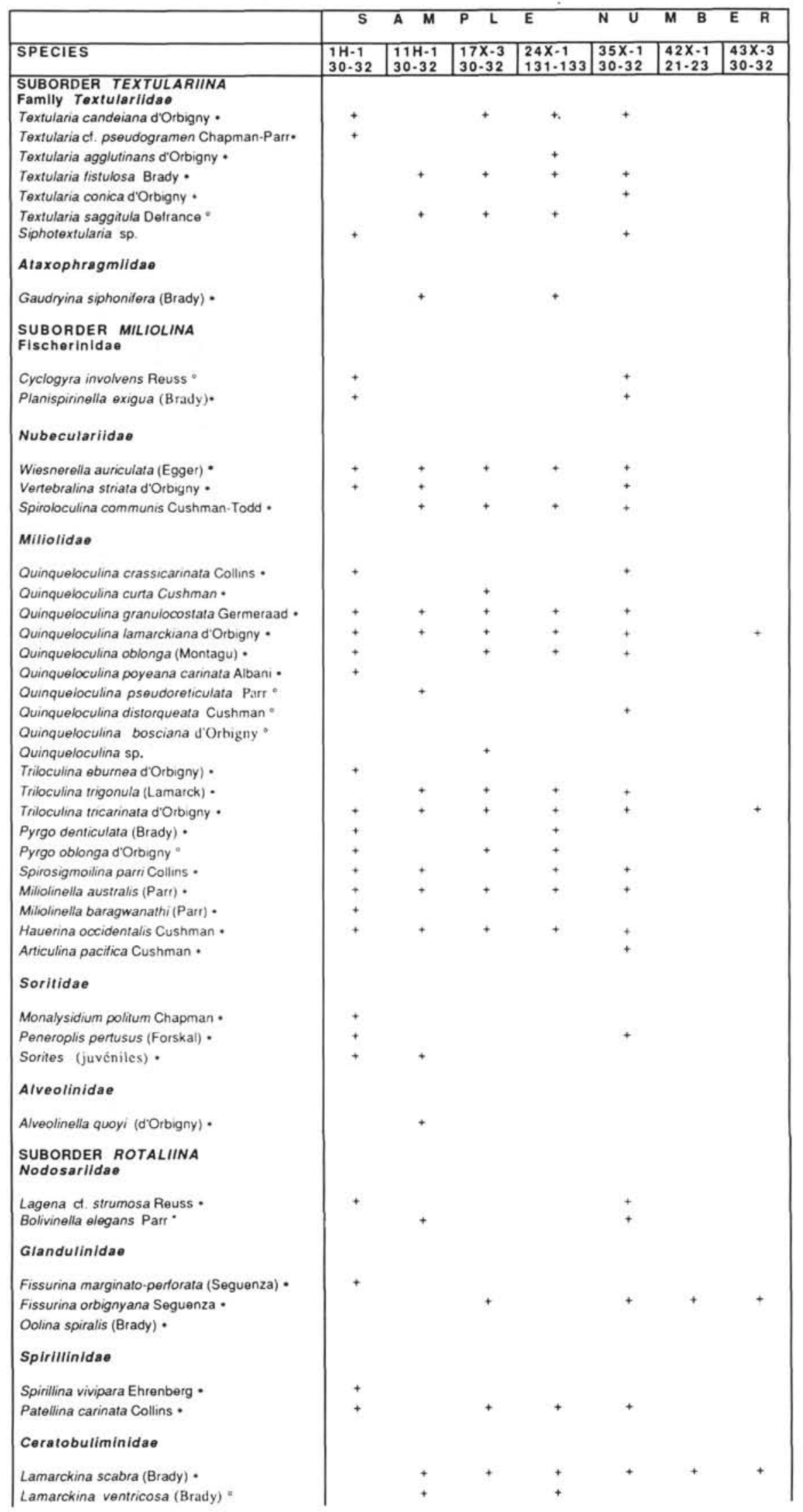


Table 1 (continued).

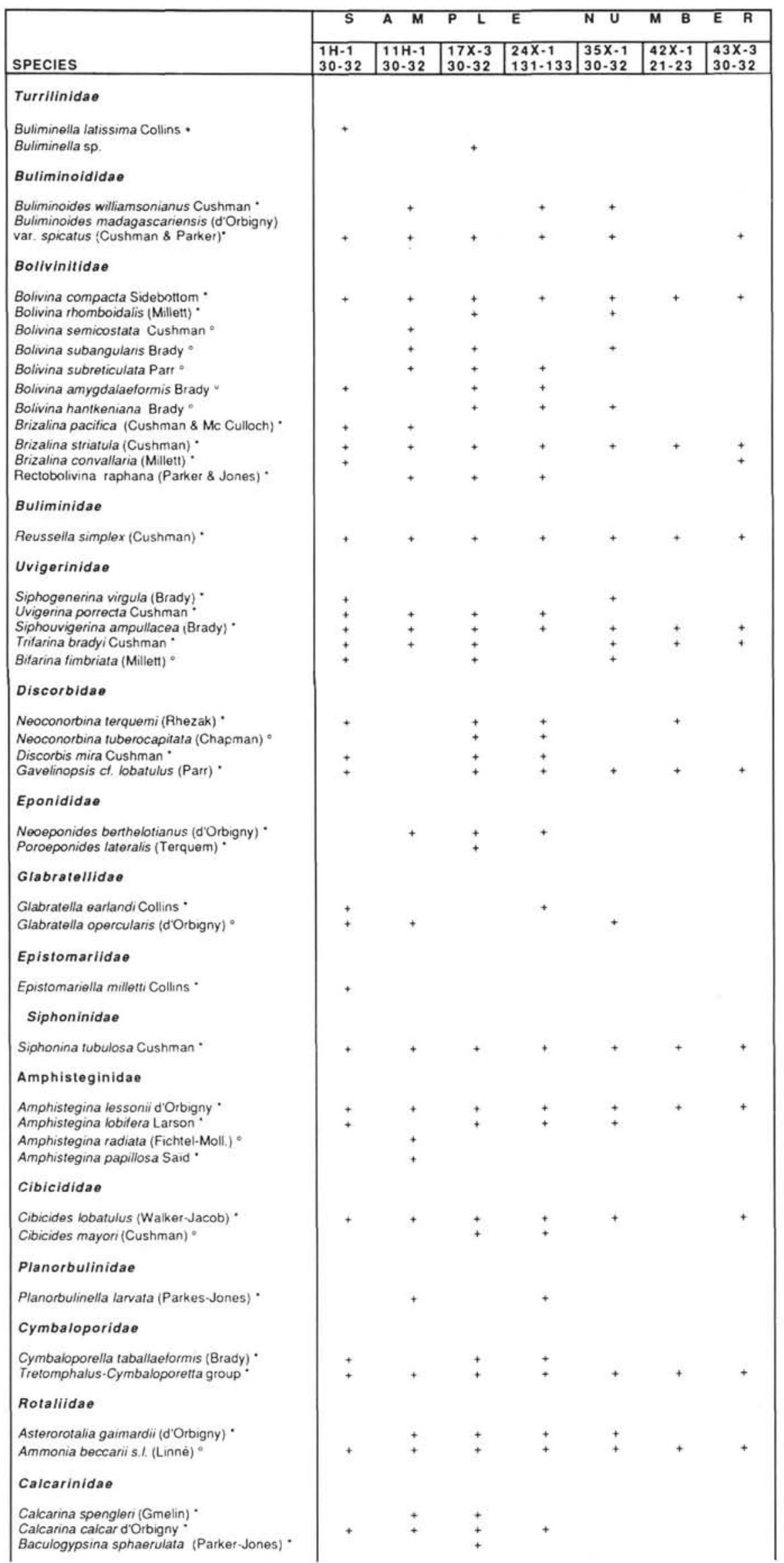


Table 1 (continued).

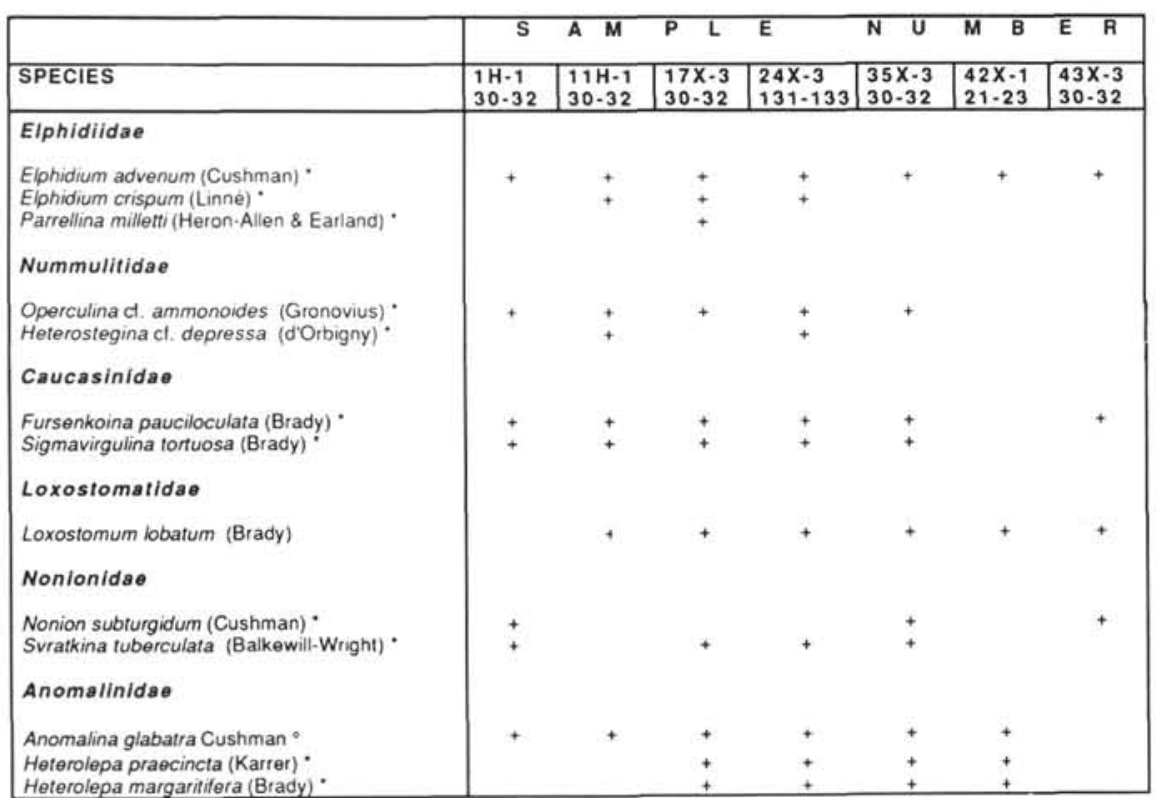

Notes: Only sediment fractions coarser than $125 \mu \mathrm{m}$ are included. Crosses indicate the occurrence of a given species in a given sample. The specific names indexed by stars refer to the faunas reported from the Great Barrier Reef environments by Collins (1958) and/or Baccaert (1987). The specific names indexed by open circles refer to the faunas not recorded by the previous authors, but present in other Indo-Pacific reef environments.

reef taxa in the GBR system, according to Baccaert (1987). Anomalinidae locally are very common $(8.3 \%)$; Heterolepa margaritifera and Anomalina glabrata, generally linked to the presence of Halimeda substrate, can exceed $3 \%$. Abundances of Cibicidae range from $0.8 \%$ to $5.7 \%$; Cibicides lobatulus, which is ubiquitous in the perireefal GBR areas, is the more typical form of this family. Concentrations of Amphistegenidae reach maximum values of $3.5 \%$; as indicated previously, Amphistegina papillosa is the most common species. Concentrations of the other families mentioned do not exceed $4 \%$ of the total benthic foraminiferal population within each sample. Similarities in the origin, taxonomic property, and frequency of the foraminiferal shells among the three samples considered strongly suggest that the nature of the successive microfaunal biocoenoses and derived taphocoenoses, which have developed throughout the platform, has remained relatively constant, as have processes of displacement and deposition during margin development.

One of the most striking features is the absence or scarceness of several larger foraminiferal species that are particularly common on modern reef environments and are considered to be typical reefdwelling GBR forms. These include arborescent foraminifers ( $\mathrm{Ho}$ motrematines, Victoriellines) occurring as active reef-binders on the present-day outer shelf-reef flats of the GBR (L.F. Montaggioni, pers. observ.), most agglutinated foraminifers, most soritids (soritines Marginopora vertebralis and Amphisorus hemprichii) and, to a lesser extent, calcarinids (Calcarina spengleri and Baculogypsina sphaerulata). Note that all these microfaunal types are even absent in the reference sample (133-821A-1H-1,30-32 cm). This indicates that the platform-derived foraminiferal taphocoenoses that were deposited along the outer slope incompletely reflect the composition of the original biocoenoses, which were partially distorted by reworking, transport, and redeposition toward the slope. The most realistic explanation for such a discrepancy comes under the basic hydrodynamic behavior of the relevant shells. Laboratory experiments conducted by Maiklem (1968) and Song (1991) demonstrated that shape, angularity, size, structure, and bulk density are major factors controlling the mode of displacement and deposition of larger foraminiferal shells.
Four grain shapes (blocks, rods, plates, and spheres) can be recognized. Arenaceous foraminifers and homotrematids produce blockshaped particles or irregularly surfaced rods that range in size from $0.5-2 \mathrm{~mm}$ to $1-5 \mathrm{~mm}$, respectively. Amphistegina lobifera (1-3 mm), A. lessonii (1-1.5 mm), and Asterorotalia gaimardii form spheroid grains. Baculogypsina and Calcarina tests, 0.5 to $1.5 \mathrm{~mm}$ in diameter, have spines on their surfaces, which make them deviate from true spheres, but their spines have been rapidly broken off or rounded by abrasion. As for soritines, these contribute to plate-shaped grains and vary from 0.5 to $8 \mathrm{~mm}$ in diameter. These different grain types differ from each other in their settling velocity and hydrodynamic stability. Plate-shaped grains settle slower than any of the other grain types. In contrast, blocks are the fastest settling particles. In the 1- to 2-mm size range, blocks and rods settle about $100 \%$ faster than do plates; the rate increases to more than $200 \%$ greater in the 3- to 5-mm range. This may explain the scarcity of agglutinated foraminifers and the absence of arborescent forms downslope, because the relevant fragments were hydrodynamically unable to be moved by suspension far from their production area. Note that, in addition, agglutinates can be rapidly disintegrated by collision and abrasion before possible longdistance transport. Among plates, soritine tests are the slowest to settle, because of their higher buoyancy and porous nature (low bulk density); when deposited, they are more stable and more resistant to the entraining shear stress associated with bottom flow than are dynamically equivalent spheric grains. The specific response of soritine shells to current energy accounts for their extreme dearth in the upper-slope deposits of the platform margin. These organisms were encountered only as juveniles in two samples. Subspheric shells, which are markedly less resistant to entrainment forces, are relatively abundant, compared with other foraminiferal types. Thus, the rotaliid Asterorotalia gaimardii represents up to $15 \%$ of Sample 133-821A$17 \mathrm{X}-3,30-32 \mathrm{~cm}$, whereas amphisteginids (mainly Amphistegina lobifera and A. lessonii) reach $2 \%$ to $3 \%$ in numerous core sections.

Nevertheless, it appears that-beyond the distortion effects from reworking, differential sorting, and deposition-a relatively close similarity in the composition of the foraminiferal taphocoenoses can 
Table 2. Relative abundance of shallower (inner-neritic) vs. deeper (outerneritic) benthic foraminifers in three representative samples from Hole 821A.

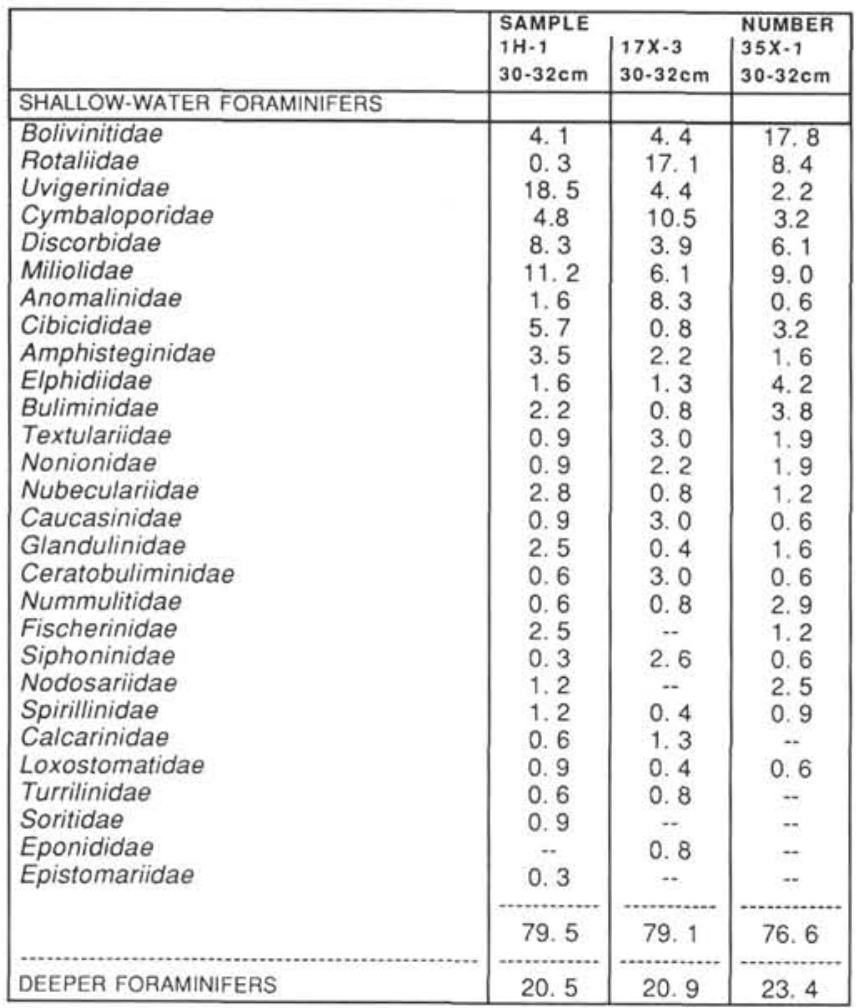

Note: The family names are arranged in decreasing order of abundance.

be seen among the various stratigraphic intervals considered and the modern GBR environments.

\section{SIGNIFICANCE OF SHALLOW-WATER FORAMINIFERAL ASSEMBLAGES}

\section{Climatic Significance}

Based on previous studies of modern distribution of benthic foraminifers (Chapman, 1900; Heron-Allen and Earland, 1915; Cushman, 1911, 1921a, 1921b, 1922, 1924, 1931, 1937, 1942; Cushman et al., 1954; Todd and Post, 1954; Graham and Militante, 1959; Todd and Low, 1960; Guilcher et al., 1965; Blanc-Vernet, 1969; Murray, 1973; Brazier, 1975; Le Calvez, 1977; Montaggioni, 1981; Vénec-Peyré, 1985, 1991; Baccaert, 1987; Hayward, 1990; Murray, 1991), we present a geographic classification of the species identified at Site 821; four reference categories were defined for convenience: (1) cosmopolitan, adapted to tropical and temperate seas; (2) cosmopolitan, exclusively tropical (Atlantic to Indo-Pacific provinces); (3) exclusively Indo-Pacific, adapted to tropical and temperate seas; (4) exclusively Indo-Pacific, exclusively tropical (Table 3 ). Attention must be paid to the fact that these results are not of absolute value, because they were established from literature data available at present; some forms considered to be exclusively tropical may have a wider latitudinal distribution area. However that may be, except for possible misinterpretations of geographic distribution, the foraminiferal assemblages studied are clearly dominated by tropical affinity forms (Table 4); about two-thirds of the species may be related to tropical shelves. Moreover, the relative abundance of exclusive tropical forms is practically similar from sample to sample. This may suggest that, on the margin, (1) climatic conditions were almost similar at the time of life of the relevant biocoenoses; and (2) tropical conditions presumably have continued through time.
Table 3. Geographic and climatic distributions of the shallow-water benthic foraminifers recorded in Hole 821A.

\begin{tabular}{|c|c|c|}
\hline \multirow{2}{*}{\multicolumn{3}{|c|}{$\frac{\text { COSMOPOLITAN }}{\text { EXCLUSIVELY }}$}} \\
\hline & & \\
\hline \multicolumn{2}{|c|}{$\begin{array}{l}\text { Textularia pseudogramen } \\
\text { Textularia agglutinans } \\
\text { Textularia saggitula } \\
\text { Vertebralina striata } \\
\text { Cyclogyra involvens } \\
\text { Ouinqueloculina oblonga } \\
\text { Quinqueloculina bosciana } \\
\text { Triloculina trigonula } \\
\text { Tribculina tricarinata } \\
\text { Pyrgo oblonga } \\
\text { Sorites sp. } \\
\text { Spinilina vivipara } \\
\text { Lamarckina scabra } \\
\text { Lamarckina ventricosa } \\
\text { Bolivina rhomboidalis } \\
\text { Brizalina pacifica } \\
\text { Brizalina striatula } \\
\text { Buliminoides williamsonianus } \\
\text { Tritarina bradyi } \\
\text { Neoconorbina terquemi } \\
\text { Discorbis mira } \\
\text { Poroeponides lateralis } \\
\text { Amphistegina lobitera } \\
\text { Cibicides iobatulus } \\
\text { Ammonia beccani } \\
\text { Elphidium crispum } \\
\text { Eiphidium advenum }\end{array}$} & $\begin{array}{l}\text { Textularia candeiana } \\
\text { Textularia conica } \\
\text { Planispininella exigua } \\
\text { Spiroloculina communis } \\
\text { Wiesnerella auriculata } \\
\text { Triloculina ebuurnea } \\
\text { Hauerina occidentalis } \\
\text { Reussella simplex } \\
\text { Bolivina compacta } \\
\text { Rectobolivina raphana } \\
\text { Neoconorbina tuberocapitata } \\
\text { Siphonina tubulosa } \\
\text { Amphistegina lessonii } \\
\text { Cibicides mayor } \\
\text { Svratkina tuberculata }\end{array}$ \\
\hline \multicolumn{3}{|c|}{$\begin{array}{l}\text { INDO-PACIFIC } \\
\text { EXCLUSIVELY TROPICAL }\end{array}$} \\
\hline THOPCAL TO TEMPERATE & EXCLUSIVELY & TROPICAL \\
\hline $\begin{array}{l}\text { Quinqueloculina curta } \\
\text { Quinqueloculina lamarckiana } \\
\text { Miliolinella australis } \\
\text { Miliolinella baragwanathi } \\
\text { Fissurina orbignyana } \\
\text { Oolina spiralis } \\
\text { Gavelinopsis lobatulus } \\
\text { Sigmavirgulina tortuosa } \\
\text { Heterolepa margaritifera }\end{array}$ & $\begin{array}{l}\text { Textularia fistulosa } \\
\text { Gaudryina siphonitera } \\
\text { Quinqueloculina crassicarinata } \\
\text { Quinqueloculina granulocostata } \\
\text { Quinqueloculina poyeana carinata } \\
\text { Quinqueloculina pseudoreticulata } \\
\text { Quinqueloculina distorqueata } \\
\text { Pyrgo denticulata } \\
\text { Spirosigmoilina parti } \\
\text { Articulina pacifica } \\
\text { Monalysidium politum } \\
\text { Peneroplis pertusus } \\
\text { Alveolinellia quoyi } \\
\text { Lagena ct. strumosa } \\
\text { Bolivinelia elegans } \\
\text { Fissurina marginato-perforata } \\
\text { Patellina caninata } \\
\text { Buliminella latissima } \\
\text { Buliminoides madagascariensis } \\
\text { var. spicatus } \\
\text { Bolivina semicostata } \\
\text { Bolivina subangularis } \\
\text { Bolivina subreticulata } \\
\text { Bolivina amygdalaeformis } \\
\text { Bolivina hantkeniana }\end{array}$ & $\begin{array}{l}\text { Brizalina convallaria } \\
\text { Siphogenerina virgula } \\
\text { Uvigerina porrecta } \\
\text { Siphouvigerina ampullacea } \\
\text { Bifarina limbriata } \\
\text { Neoeponides berthelotianus } \\
\text { Glabratella eartandi } \\
\text { Glabratella opercularis } \\
\text { Epistomariella milletti } \\
\text { Amphistegina radiata } \\
\text { Amphistegina papillosa } \\
\text { Planorbutinella lavata } \\
\text { Cymbaloporella taballaeformis } \\
\text { Cymbaioporetta-Tretomphalus } \\
\text { Asterorotalia gaimardii } \\
\text { Calcarina spengleri } \\
\text { Calcarina calcar } \\
\text { Baculogypsina sphaerulata } \\
\text { Parrellina milletti } \\
\text { Operculvina ammonoides } \\
\text { Heterostegina depressa } \\
\text { Fursenkoina pauciloculata } \\
\text { Loxostomum lobatum } \\
\text { Nonion subturgidum } \\
\text { Anomalina glabrata } \\
\text { Heterolopa praecincta }\end{array}$ \\
\hline
\end{tabular}

\section{Environmental Significance}

Hottinger (1983) and Hallock \& Glenn (1986) proposed models of distributions of larger foraminifers by depth and substrate types for Cenozoic tropical shelf areas on the basis of modern analogs. Baccaert (1987) provided a summary of the succession of the foraminiferal species living in the various reef environments around the Lizard Island area; species have been regarded as characteristic of a given environment on the basis of their persistent occurrence and/or abundance in the relevant taphocoenosis. Previously, Collins (1958) indicated broad zones where the species collected from the northern GBR province occur, as well as their abundances. These distributional schemes have been used here as reference categories for characterization of neritic, platform-related environments. Three main types of environments have been recognized: high- to medium-energy, open environments (outer platform area, platform edge) vs. low-energy, and restricted ones (inner platform area) (Table 5).

In the Indo-Pacific Province, extensive outer platform areas and fore-slopes within the euphotic zone ( 30 to about $130 \mathrm{~m}$ deep) are typified by agglutinates (diverse textulariids), large flattened rotaliines (Amphistegina radiata, A. papillosa, Heterostegina, and Operculina), and some large, very flat soritids. Shallower areas (less than $30-40 \mathrm{~m}$ ) are dominated by intermediate rotaliines (Amphistegina lessonii), alveolinids (Alveolinella quoyi), soritids (Monalysidium, Peneroplis pertusus, Sorites) and nummulitids. Smaller foraminifers include some textulariids, nubeculariids (Spiroloculina communis), numerous miliolids (Quinqueloculina crassicarinata, Q. granulocostata, Q. lamarckiana; Triloculina; Spirosigmoilina parri), buliminids (Reussella sim- 
Table 4. Species number and relative abundance of the various climate-related categories of shallow-water benthic foraminifers recorded in Hole 821A.

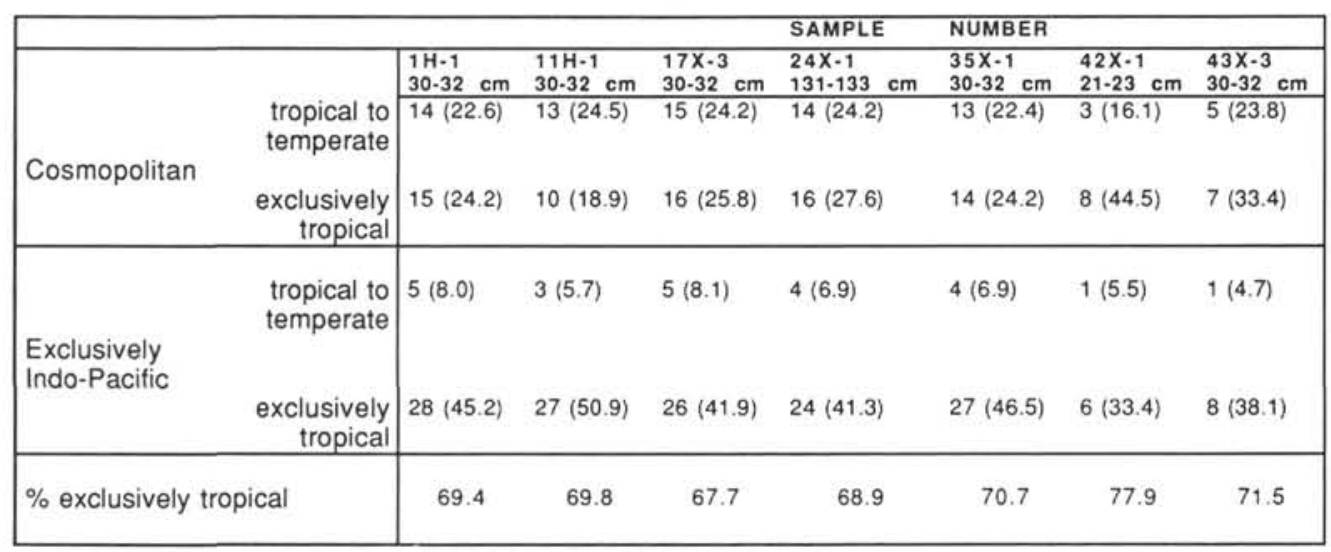

Notes: The numbers without brackets refer to the number of species recorded in each sample; the numbers in brackets refer to the percentage of species belonging to each climate-related category in each sample.

plex), uvigerinids (Siphouvigerina ampullacea), discorbids (Neocorbina terquemi, Gavelinopsis lobatulus), eponidids (Neoeponides, Poroeponides), siphoninids (Siphonina tubulosa), cibicids (Cibicides lobatulus), rotaliids (Ammonia beccarii), elphidiids (Elphidium advenum), caucasinids (Fursenkoina pauciloculata), loxostomids (Loxostomum lobatum), Nonionids (Nonion subturgidum), and anomalinids (Heterolepa praecincta).

The foraminiferal fauna of the platform edge represents a variety of forms mainly living in intertidal to slightly subtidal, high-energy environments. These assemblages are dominated by robust ovoids to subspheric rotaliines (Amphistegina lobifera, Calcarina, Baculogypsina). Miliolines and small rotaliines also are common: nubeculariids (Vertebralina striata), miliolids (Quinqueloculina curta, Miliolinella baragwanathi), bolivinids (Bolivina compacta, B. rhomboidalis), buliminoidids (Buliminoides madagascariensis spicatus), uvigerinids (Rectobolivina raphana), discorbids (Discorbis mira), cymbaloporids (Cymbaloporella, Cymbaloporetta), rotaliids (Asterorotalia gaimardii), and elphidiids (Elphidium crispum, Parrellina milletti).

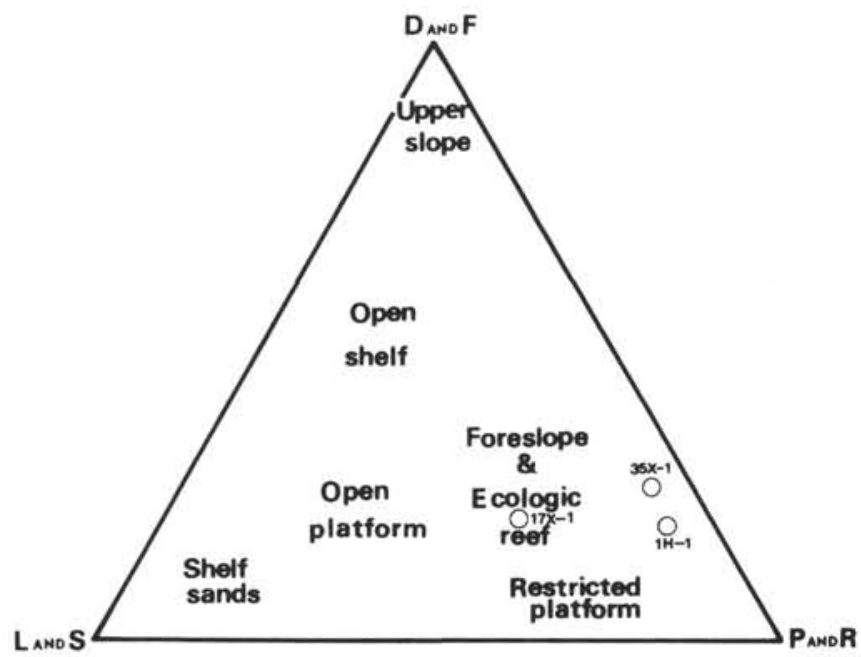

Figure 4. Triangular diagram showing the distribution of foraminiferal assemblages from each of Wilson's standard facies, according to the method of Hallock and Glenn (1986, modified): D and F = deeper benthics and flat rotaliines; $\mathrm{L}$ and $\mathrm{S}=$ lenticular and subspheroid large rotaliines (including Amphistegina, Asterorotalia, Heterolepa); $\mathrm{P}$ and $\mathrm{R}=$ porcelaneous forms (including miliolines) and smaller rotaliines.
The inner platform areas having depths of less than $30 \mathrm{~m}$ exhibit diverse foraminiferal faunas. Miliolines, intermediate to small rotaliines, dominate as epiphytal forms dwelling in cyanobacterial film and macroalgal coat substrata. Among rotaliines, the most frequent species belong to the glandulinids (Fissurina orbignyana), buliminids (Reussella simplex), bolivinitids (Brizalina striatula, B. convallaria), uvigerinids (Siphouvigerina ampullacea), discorbids (Neocorbina terquemi, Gavelinopsis cf. lobatulus), siphoninids (Siphonina tubulosa), cymbaloporids, rotaliids (Ammonia beccarii, Asterorotalia gaimardii), elphidiids (Elphidium advenum), caucasinids (Fursenkoina pauciloculata), loxostomids, and anomalinids (Heterolepa praecincta). Miliolines are mainly represented by Quinqueloculina granulocostata, $Q$. oblonga, Triloculina trigonula, and Hauerina occidentalis. Larger foraminifers (soritids, Amphistegina lessonii, A. radiata) are locally prolific.

In modern Indo-Pacific tropical platforms, the most diagnostic foraminiferal species of reef environment are those possessing robust and thick tests and that have, thus, adapted to high light intensity and high water turbulence (Hallock and Glenn, 1986). Among the species listed by Baccaert (1987) in the taphocoenoses from the Lizard Island area, $31 \%$ are typical of platform edge areas (reef flats, proximal shallow back-reef zones). This value is close to that (36\%) obtained from the whole species collected at Site 821. The reference sample (133- $821 \mathrm{~A}-1 \mathrm{H}-1,30-32 \mathrm{~cm}$ ), which presents $34 \%$ of turbulencetolerating species, gives a faithful picture of the composition of the Holocene foraminiferal accumulations on the GBR. The relative abundance of these species in the other samples studied varies as follows: $18.5 \%$ at interval $133-821 \mathrm{~A}-11 \mathrm{H}-1,30-32 \mathrm{~cm} ; 34 \%$ at interval $-17 \mathrm{X}-3$, $30-32 \mathrm{~cm} ; 30.5 \%$ at interval $-24 X-1,131-133 \mathrm{~cm} ; 27.0 \%$ at interval $-35 \mathrm{X}-1,30-32 \mathrm{~cm} ; 12 \%$ at interval $-42 \mathrm{X}-1,21-23 \mathrm{~cm}$, and $23.8 \%$ at interval $-43 X-3,30-32 \mathrm{~cm}$. Two hypotheses emerge from these results: (1) the frequency of the high-energy adapted species may be virtually equivalent throughout the upper two-thirds of the cored sedimentary series; (2) even in the lowermost, intensively altered beds, the amounts of the characteristic species are significant. This indicates that at Site 821 during the last $1.4 \mathrm{~m} . \mathrm{y}$. the margin slope was regularly supplied from high-energy microfaunal communities, thereby demonstrating the persistence of platform edges through time along the northern Australian shelf. This contention is supported by the triangular plotting of the quantitative foraminiferal data obtained from the intervals 133821A-1H-1, 30-32 cm; -17X-3, 30-32 cm; and $-35 \mathrm{X}-1,30-32 \mathrm{~cm}$. According to Hallock and Glenn (1986), the triangular diagram (Fig. 4) shows where the microfaunal assemblages from each of Wilson's standard facies (1974) are plotted. The plot of the samples denotes reef flat to proximal lagoonal environments (i.e., high- to moderate-energy conditions on platform edges). 
Table 5. Distribution of the shallow-water foraminiferal species in Hole 821A in their main environments of life (outer platform, platform edge, and inner platform).

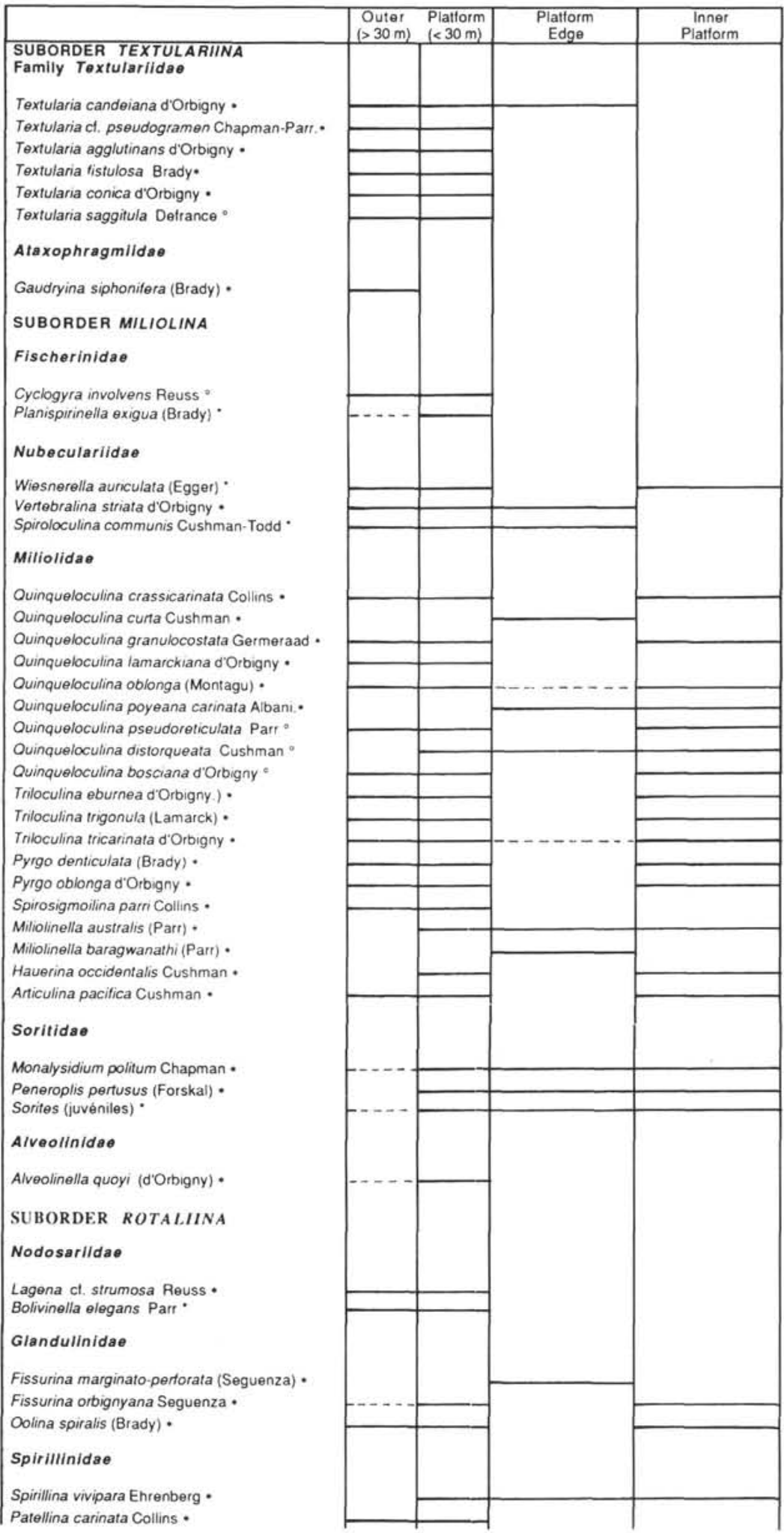

Notes: Solid lines refer to species characteristic of a given environment. Dashed line refers to species present, but not regarded as characteristic. Data from Collins (1958), Hallock and Glenn (1986), and Baccaert (1987). 
Table 5 (continued).

\begin{tabular}{|c|c|c|c|}
\hline & $\begin{array}{|cc|}\text { Outer } & \text { Plartorm } \\
(>30 \mathrm{~m}) & (<30 \mathrm{~m}) \\
\end{array}$ & $\begin{array}{c}\text { Platform } \\
\text { Edge }\end{array}$ & $\begin{array}{c}\text { Inner } \\
\text { Plattorm }\end{array}$ \\
\hline \multicolumn{4}{|l|}{ Ceratobuliminidae } \\
\hline \multirow{2}{*}{\multicolumn{4}{|c|}{$\begin{array}{l}\text { Lamarckina scabra }(\mathrm{Brady}) \text {. } \\
\text { Lamarckina ventricosa (Brady) }\end{array}$}} \\
\hline & & & \\
\hline \multicolumn{4}{|l|}{ Turrilinidae } \\
\hline \multicolumn{4}{|l|}{ Buliminella latissima Collins. } \\
\hline \multicolumn{4}{|l|}{ Buliminoididae } \\
\hline \multirow{2}{*}{\multicolumn{4}{|c|}{$\begin{array}{l}\text { Buliminoides williamsonianus Cushman } \\
\text { Buliminoodes madagascariensis (d'Orbigny) } \\
\text { var. spicatus (Cushman \& Parker). }\end{array}$}} \\
\hline & & & \\
\hline \multicolumn{4}{|l|}{ vali spicalus (Cushman \& Parker) } \\
\hline \multicolumn{4}{|l|}{ Bolivina compacta Sidebottom. } \\
\hline \multicolumn{4}{|l|}{$\begin{array}{l}\text { Bolivina compacta Sidebottom. } \\
\text { Bolivina rhomboidalis (Milett) }\end{array}$} \\
\hline \multicolumn{4}{|l|}{$\begin{array}{l}\text { Bolvina thomboidalis (Mileti). } \\
\text { Bolivina semicostata Cushman. }\end{array}$} \\
\hline \multicolumn{4}{|l|}{ Bolivina subangularis Brady" } \\
\hline \multicolumn{4}{|l|}{ Bolivina subreticulata Part: } \\
\hline \multirow{2}{*}{\multicolumn{4}{|c|}{$\begin{array}{l}\text { Bolivina amygdalaetormis Brady. } \\
\text { Bolivina hantkeniana Brady" }\end{array}$}} \\
\hline \multicolumn{3}{|l|}{$\begin{array}{l}\text { Bolivina hantkeniana Brady" } \\
\text { Brizalina pacifica (Cushman \& Mc Culloch). }\end{array}$} & \\
\hline \multirow{2}{*}{\multicolumn{4}{|c|}{$\begin{array}{l}\text { Brizalina pacifica (Cushman \& Mc Culloch) } \\
\text { Brizalina striatula (Cushman): } \\
\text { Brizalina convallaria (Millett). }\end{array}$}} \\
\hline \multirow{2}{*}{\multicolumn{4}{|c|}{ Buliminidae }} \\
\hline & & & \\
\hline \multicolumn{3}{|l|}{ Reussella simplex (Cushman) * } & \\
\hline \multicolumn{4}{|l|}{ Uvigerinidae } \\
\hline \multicolumn{4}{|l|}{ Siphogenerina virgula (Brady.). } \\
\hline \multicolumn{4}{|l|}{$\begin{array}{l}\text { Siphogenerina Virgula (Brady.)" } \\
\text { Uvigerina porrecta Cushnian " }\end{array}$} \\
\hline \multicolumn{2}{|l|}{$\begin{array}{l}\text { Siphouvigerina ampullacea (Brady) } \\
\text { Trifarina bradyi Cushman * }\end{array}$} & & \\
\hline \multicolumn{4}{|l|}{$\begin{array}{l}\text { Trifarina bradyi Cushman } \\
\text { Bifarina fimbriata (Millett) }\end{array}$} \\
\hline \multicolumn{4}{|l|}{ Discorbidae } \\
\hline Neoconorbina terquemi (Rhezak) & & & \\
\hline Neoconorbina tuberocapitata (Chapman.) & $-\cdots$ & & \\
\hline $\begin{array}{l}\text { Discorbis mira Cushman. } \\
\text { Gavelinopsis of lobatulus (Parr). }\end{array}$ & & & \\
\hline Eponididae & & & \\
\hline Neoeponides berthelotianus (d'Orbigny) & & & \\
\hline Poroeponides lateralis (Terquem) * & & & \\
\hline Glabratellidae & & & \\
\hline $\begin{array}{l}\text { Glabratelia earlandi Collins } \\
\text { Glabratella opercularis (d'Orbigny) }\end{array}$ & & & \\
\hline Epistomariidae & & & \\
\hline Epistomariella millett Collins ${ }^{*}$ & & & \\
\hline Siphoninidae & & & \\
\hline Siphonina tubulosa Cushman . & & & \\
\hline Amphisteginidae & & & \\
\hline $\begin{array}{l}\text { Amphistegina lessonii d'Orbigny . } \\
\text { Amphistegina lobifera Larsen. }\end{array}$ & & & \\
\hline $\begin{array}{l}\text { Amphistegina radiata (Fichtel-Moll.) } \\
\text { Amphistegina paoillosa Said. }\end{array}$ & & & \\
\hline $\begin{array}{l}\text { Amphistegina papillosa Said } \\
\text { Cibicididae }\end{array}$ & & & \\
\hline Cibicididae & & & \\
\hline $\begin{array}{l}\text { Cibicides lobatulus (Walker-Jacob) } \\
\text { Cibicides mayori (Cushman) }\end{array}$ & & & \\
\hline Planorbulinidae & & & \\
\hline Planorbulinella larvata (Parkes Jones) * & & & \\
\hline Cymbaloporidae & & & \\
\hline $\begin{array}{l}\text { Cymbaloporella taballaeformis (Brady). } \\
\text { Tretomphalus-Cymbaloporetta group. }\end{array}$ & & & \\
\hline
\end{tabular}


Table 5 (continued).

\begin{tabular}{|c|c|c|c|c|}
\hline & \begin{tabular}{|l|} 
Outer \\
$(>30 \mathrm{~m})$ \\
\end{tabular} & $\begin{array}{l}\text { Platform } \\
(<30 \mathrm{~m})\end{array}$ & $\begin{array}{l}\text { Platform } \\
\text { edge }\end{array}$ & $\begin{array}{l}\text { Inner } \\
\text { Platiorm } \\
\end{array}$ \\
\hline \multicolumn{5}{|l|}{ Rotaliidae } \\
\hline \\
\hline Ammonia beccarii s.l. (Linné) ${ }^{\circ}$ & & & & \\
\hline \multicolumn{5}{|l|}{ Calcarinidae } \\
\hline \\
\hline & & & & \\
\hline \multicolumn{5}{|l|}{$\begin{array}{l}\text { Baculogypsina sphaerulata (Parker-Jones). } \\
\text { Parrellina milletti (Heron-Allen \& Earland). }\end{array}$} \\
\hline \multirow{2}{*}{\multicolumn{5}{|c|}{ Elphidiidae }} \\
\hline & & & & \\
\hline \multicolumn{5}{|l|}{$\begin{array}{l}\text { Elphidium advenum (Cushman) } \\
\text { Eiphidium crispum (Linné). }\end{array}$} \\
\hline \multicolumn{5}{|l|}{ Nummulitidae } \\
\hline \multirow{2}{*}{\multicolumn{5}{|c|}{$\begin{array}{l}\text { Operculina ct: ammonoides } \\
\text { Heterostegina cf depressa }\end{array}$}} \\
\hline & & & & \\
\hline \multicolumn{5}{|l|}{ Caucasinidae } \\
\hline \multicolumn{5}{|l|}{$\begin{array}{l}\text { Fursenkoina pauciloculata (Brady). } \\
\text { Sigmavirgulina tortuosa (Brady) }\end{array}$} \\
\hline \multirow{2}{*}{\multicolumn{5}{|c|}{ Loxostomatidae }} \\
\hline & & & & \\
\hline \multicolumn{5}{|l|}{ Loxostomum lobatum (Brady)" } \\
\hline \multicolumn{5}{|l|}{ Nonionidae } \\
\hline \multirow{2}{*}{\multicolumn{5}{|c|}{$\begin{array}{l}\text { Nonion subturgidum (Cushman). } \\
\text { Suratkina tuberculata (Balkwill-Wright) }\end{array}$}} \\
\hline \multirow{2}{*}{\multicolumn{5}{|c|}{ Anomalinidae }} \\
\hline & & & & \\
\hline \multicolumn{5}{|l|}{ Anomalina glabatra Cushman = } \\
\hline Heterolepa praecincta (Karrer) . & & & & \\
\hline Heterolepa marganitifera (Brady). & & & & \\
\hline
\end{tabular}

\section{DISCUSSION: IMPLICATIONS FOR THE GROWTH HISTORY OF THE CENTRAL GREAT BARRIER REEF}

Several lines of evidence emerge after the analysis of the composition and distribution of shallow-water foraminiferal assemblages at Site 821:

1. The whole species recorded throughout Hole $821 \mathrm{~A}$ are living in various reef sites throughout the Indo-Pacific and Caribbean provinces.

2. A relatively close similarity is seen in the nature and composition of the taphocoenoses among the different stratigraphic intervals studied and the modern GBR environments.

3. Environmental and climatic conditions were relatively stable during deposition of the successive microfaunal assemblages studied; inner-neritic, tropical environments developed repeatedly throughout Pleistocene time.

4. High- to moderate-energy platform edges formed repeatedly during the last 1.4 m.y.

From the foregoing, one can see that environmental factors favorable to reef development may have occurred several times at least, if not maintained constantly, since the beginning of the Quaternary along the northern Australian margin. Davies, McKenzie, Palmer-Julson, et al., (1991, p. 485), postulated that, in this region, reef growth was inhibited from the early Pliocene until the initiation of the GBR system; no major barrier reef would have existed along the Queensland margin for about $2 \mathrm{~m}$.y. Similarly, based on lithological and geophysical surveys on the GBR shelf edge and adjacent slope at Sites 819 to 821 , Feary et al. (this volume) point out that the most likely period for reef growth initiation in the central GBR area corresponds to the time of deposition of Units II and III, and more accurately, of the top of Unit II (age range: $0.5-1 \mathrm{~m} . \mathrm{y}$.). If this is correct, the factors responsible for inhibition of reef growth, especially during basically favorable periods, should have operated on a regional scale only (i.e., restricted to the central part of the Queensland shelf). Indeed, during the early Pleistocene, reef sys- tems flourished in various areas of the West Pacific Ocean. Seismic data (Davies et al., 1988) from the northern GBR area and the outer Papuan shelf indicate the presence of buried relict Pliocene-Pleistocene shelf-edge reefs of varying thickness. Coudray (1976) reported the occurrence of a 120-m-thick reef tract, dated 1 to $1.5 \mathrm{Ma}$., beneath the modern New Caledonian reef province. Carney et al. (1985) also stated that successive regressive fringing reef complexes developed around the flanks of various uplifted Vanuatu islands throughout late Pliocene-Pleistocene time. The foraminiferal data presented here indicate that (1) climatic and environmental reef growth-inhibiting conditions cannot have operated throughout the early and intermediate Pleistocene; (2) reef-like bodies may have formed repeatedly on the platform as the slope was prograding. The bodies that may have developed at the time of deposition of interval 133-821A-24X-1, 131-133 $\mathrm{cm}$ (age: older than 1 m.y.), would be coeval with small reefal mounds seismically discovered on the GBR shelf edge in Unit IV, within the progradational package, by Feary et al. (this volume). The hypothesis conflicts with the previously advanced contention by Davies, McKenzie, Palmer-Julson, et al. (1991, p. 405). Reef development was probably not inhibited during the early Pleistocene. In fact, the most important questions to be raised are: (1) what geometry and size do former reef systems from the Queensland margin require to be regarded as the incipient GBR system? (2) Must the GBR concept be exclusively restricted to wider and semicontinuous lines of build-ups able to induce dramatic changes in the style of sedimentation on the adjacent slope? If the term GBR refers to the history of a major reef system having channelled major low-sea-level deposition and thus controlled the transition from progradational to aggradational sedimentary regime onto the northwestern Australian margin, the reefs that may have grown during the early Pleistocene cannot probably be regarded as the direct precursors of the present-day GBR tract. In contrast, if the GBR concept can be applied to the history of all reefs that have developed and evolved in-situ along the edge of the Queensland margin, such reefs were the actual cradle of the GBR complex. We suggest that since early Pleistocene time, scattered but morphologically well 
differentiated reef systems grew successively on the central north Australian shelf edge; these exhibited sufficiently various environments (reef flat to back-reef zones) to serve as habitats for foraminiferal biocoenoses of high specific diversity. The modern GBR system might be only the final evolution of successive reef tracts that have developed since the beginning of the Quaternary.

\section{ACKNOWLEDGMENTS}

LFM is indebted to the ODP-French Committee for giving the opportunity of participating in Leg 133. Special thanks are extended to the Institut National des Sciences de l'Univers - CNRS for providing financial support. Thanks also to G. Glaçon for help with laboratory treatment of samples and Laroche for SEM analysis. Comments and suggestions by B. McGowran and T. Scoffin have improved an early draft of the manuscript.

\section{REFERENCES}

Baccaert, J., 1987. Distribution patterns and taxonomy of benthic foraminifera in the Lizard Island reef complex, northern Great Barrier Reef, Australia [Ph.D. dissert.]. Liege Univ., Belgium.

Blanc-Vernet, L., 1969. Contribution à l'étude des foraminifères de Méditerranée. Relations entre la microfaune et les sédiments; biocoenoses actuelles, thanatocoenoses Pliocènes et Quaternaires. Rec. Trav. Stat. Mar. Endoume, 64-68:1-281.

Brazier, M.D., 1975. Ecology of Recent sediment-dwelling and phytal foraminifera from the lagoons of Barbuda, West Indies. J. Foraminiferal Res., 5:42-62.

Carney, J.N., Macfarlane, A., and Mallick, D.I.J., 1985. The Vanuatu island arc: an outline of the stratigraphy, structure, and petrology. In Nairn, A.E.M. Stehli, F.G., and Uyeda, S. (Eds.), The Ocean Basins and Margins (Vol. 7): New York (Plenum), 685-718.

Chapman, F., 1900. Foraminifera from the lagoon at Funafuti. Linn. J. Zool., 28:161-210.

Collins, A.C., 1958. Foraminifera. Great Barrier Reef Expedition 1928-29, Sci. Rep., 6:335-437.

Coudray, J., 1976. Recherches sur le Néogène et le Quaternaire Marin de la Nouvelle-Calédonie: Expéd. Franç. Récifs Coralliens Nouvelle-Calédonie: Paris (Singer-Polignac).

Cushman, J.A., 1911. A monograph of Foraminifera of the North Pacific Ocean. Part 2: Textulariidae. Bull. U.S. Nat. Mus., 71:1-46.

, 1921a. Foraminifera of the North coast of Jamaica. Proc. U.S. Nat. Mus., 59:1-85.

, 1921b. Foraminifera of the Philippines and adjacent seas. Bull. U.S. Nat. Mus., 100:1-608.

1922. Shallow water Foraminifera of the Tortugas region. Carnegie Inst. Washington Publ., 311:1-85.

- 1924. Samoan Foraminifera. Carnegie Inst. Washington Publ., 342:1-75.

1931. The Foraminifera of the Atlantic Ocean, Part 8. Bull. U.S Nat. Mus., 104:1-179.

, 1932-1942. The Foraminifera of the tropical Pacific collections of the Albatross, 1899-1900. Bull. U.S. Nat. Mus., 161:(1) 1-85, (2) 1-79, (3) 1-67. -1937. A monograph of the subfamily Virgulininae of the foraminiferal family Buliminidae. Spec. Publ. Cushman Lab. Foraminiferal, 9:1-228.

Cushman, J.A., Todd, R., and Post, R.J., 1954. Recent Foraminifera of the Marshall islands, Bikini and nearby atolls. Part 2: Oceanography (Biology). Geol. Surv. Prof. Pap. U.S., 260-H:319-384.

Davies, P.J., McKenzie, J.A., Palmer-Julson, A., et al., 1991. Proc. ODP, Init. Repts., 133: College Station, TX (Ocean Drilling Program).

Davies, P.J., Symonds, P.A., et al., 1988. Rig Seismic Research Cruises 4 and 5: northeast Australia post-cruise report. Rep. Bur. Miner. Resour, Geol. Geophys. (Aust.), 281.

Davies, P.J., Symonds, P.A., Feary, D.A., and Pigram, C.J., 1987. Horizontal plate motion: a key allocyclic factor is the evolution of the Great Barrier Reef. Science, 238:1697-1700.

1989. The evolution of the carbonate platforms of North-East Australia. Spec. Publ.-Soc. Econ. Paleontol. Mineral., 44:233-258.

\footnotetext{
Abbreviations for names of organizations and publication titles in ODP reference lists follow the style given in Chemical Abstracts Service Source Index (published by American Chemical Society).
}

Feary, D.A., Davies, P.J., Pigram, C.J., and Symonds, P.A., 1991. Climatic evolution and control on carbonate deposition in Northeast Australia. Palaeogeogr., Palaeoclimatol., Palaeoecol., 89:341-361.

Graham, J.J., and Militante, P.J., 1959. Recent Foraminifera from the Puerto Galera area, Northern Mindoro, Philippines. Stanford Univ. Publ., Geol. Sci., 6:1-127.

Guilcher, A., Berthois, L., Le Calvez, Y., Battistini, R., and Crosnier., A., 1965. Les récifs coralliens et le lagon de l'île Mayotte (Archipel des Comores, Océan Indien). Mem. ORSTOM, 11:1-201.

Hallock, P., and Glenn, C.E., 1986. Larger Foraminifera: a tool for paleoenvironmental analysis of Cenozoic carbonate depositional facies. Palaios, 1:55-65.

Hayward, B.W., 1990. Taxonomy, paleobiogeography and evolutionary history of the Bolivinellidae (Foraminiferida). N.Z. Geol. Surv., Paleontol. Bull., 63:1-132.

Heron-Allen, E., and Earland, A., 1915. The Foraminifera of the Kerimba archipelago (Portuguese East Africa). Trans. Zool. Soc. London, 20:543-790.

Hirshfield, H.I., Charmatz R., and Helson, J., 1968. Foraminifera in samples taken mainly from Eniwetok atoll in 1956. J. Protozool., 15:497-502.

Hottinger, L., 1983. Processes determining the distribution of larger Foraminifera in space and time. Utrecht Micropaleontol. Bull., 30:239-253.

Le Calvez, Y., 1977. Révision des Foraminiferes de la collection d'Orbigny. II. Foraminifères de l'île de Cuba. Cah. Micropaleontol., 1:1-127.

Le Calvez, Y., and Salvat, B., 1980. Foraminiferes des récifs et lagons coralliens de Moorea, île de la Société. Cah. Micropaleontol., 4:1-15.

Leutenegger, S., 1984. Symbiosis in benthic foraminifera: specificity and host adaptation. J. Foraminiferal Res., 14:16-35.

Lloyd, A.R., 1973. Foraminifera of the Great Barrier Reef bores. In Jones, O.A., and Endean R. (Eds.), Biology and Geology of Coral Reefs (Vol. 1): New York (Academic Press), 347-366.

Loeblich, A.R., and Tappan, H., 1974. Recent advances in the classification of the Foraminiferida. In Hedley, R.H., and Adams, C.G. (Eds.), Foraminifera (Vol. 1): London (Academic Press): 1-53.

Maiklem, W.R., 1968. Some hydraulic properties of bioclastic carbonate grains. Sedimentology, 10:101-110.

Maxwell, W.G.H., 1968. Atlas of the Great Barrier Reef: Amsterdam (Elsevier).

Montaggioni, L.F., 1981. Les associations de Foraminifères dans les sédiments récifaux de l'archipel des Mascareignes (Océan Indien). Ann. Inst. Oceanogr. (Paris), 57:41-62.

Montaggioni, L.F., Behairy, A.K.A., El-Sayed, M.K., and Yusuf, N., 1986. The modern reef complex, Jeddah area, Red Sea: a facies model for carbonate sedimentation on embryonic passive margins. Coral Reefs, 5:127-150.

Murray, J.W., 1973. Distribution and Ecology of Living Benthic Foraminiferids: London (Heinemann Educational Books).

, 1991. Ecology and Paleoecology of Benthic Foraminifera: Harlow (Longman. Scient. Techn.).

Poag, C.W., and Tresslar, R.G., 1981. Living Foraminifers of West Flower Garden bank, northernmost coral reef in the Gulf of Mexico. Micropaleontology, 27:31-70.

Scoffin, T.P., and Tudhope, A.W., 1985. Sedimentary environments of the central region of the Great Barrier Reef of Australia. Coral Reefs, 4:81-93.

Song, Y., 1991. Hydrodynamic differentiation between two reef-building larger Foraminifera in relation to habitat disparation. Int. Soc. Reef Stud. Meeting, Berkeley, Abstracts, 61.

Symonds, P.A., Davies, P.J., and Parisi, A., 1983. Structure and stratigraphy of the central Great Barrier Reef. BMR J. Aust. Geol. Geophys., 8:277-291.

Todd, R., and Low, D., 1960. Smaller foraminifera from Eniwetok drillholes. Geol. Surv. Prof. Pap. U.S., 260X:799-861.

Todd, R., and Post. R., 1954. Bikini and nearby atolls, Marshall islands: smaller foraminifera from Bikini drillholes. Geol. Surv. Prof. Pap. U.S., 260M:547-568.

Tudhope, A.W., and Scoffin, T.P., 1988. The relative importance of benthic foraminiferans in the production of carbonate sediment on the central Queensland shelf. Proc. 6th Int. Coral Reef Symp., 2:583-588.

Vénec-Peyré, M.T., 1985. Etude de la distribution des Foraminifères vivants dans le lagon de l'île haute volcanique de Mooréa (Polynésie Française). Proc. 5th Int. Coral Reef Symp., 5:227-232.

1991. Distribution of living benthic Foraminifera on the backreef and outer slopes of high islands (Moorea, French Polynesia). Coral Reefs, 9:193-203.

Wilson, J.L., 1974. Characteristics of carbonate platform margins. AAPG Bull., 58:810-824.

\section{Date of initial receipt: 6 April 1992 \\ Date of acceptance: 13 October 1992 \\ Ms 133SR-246}




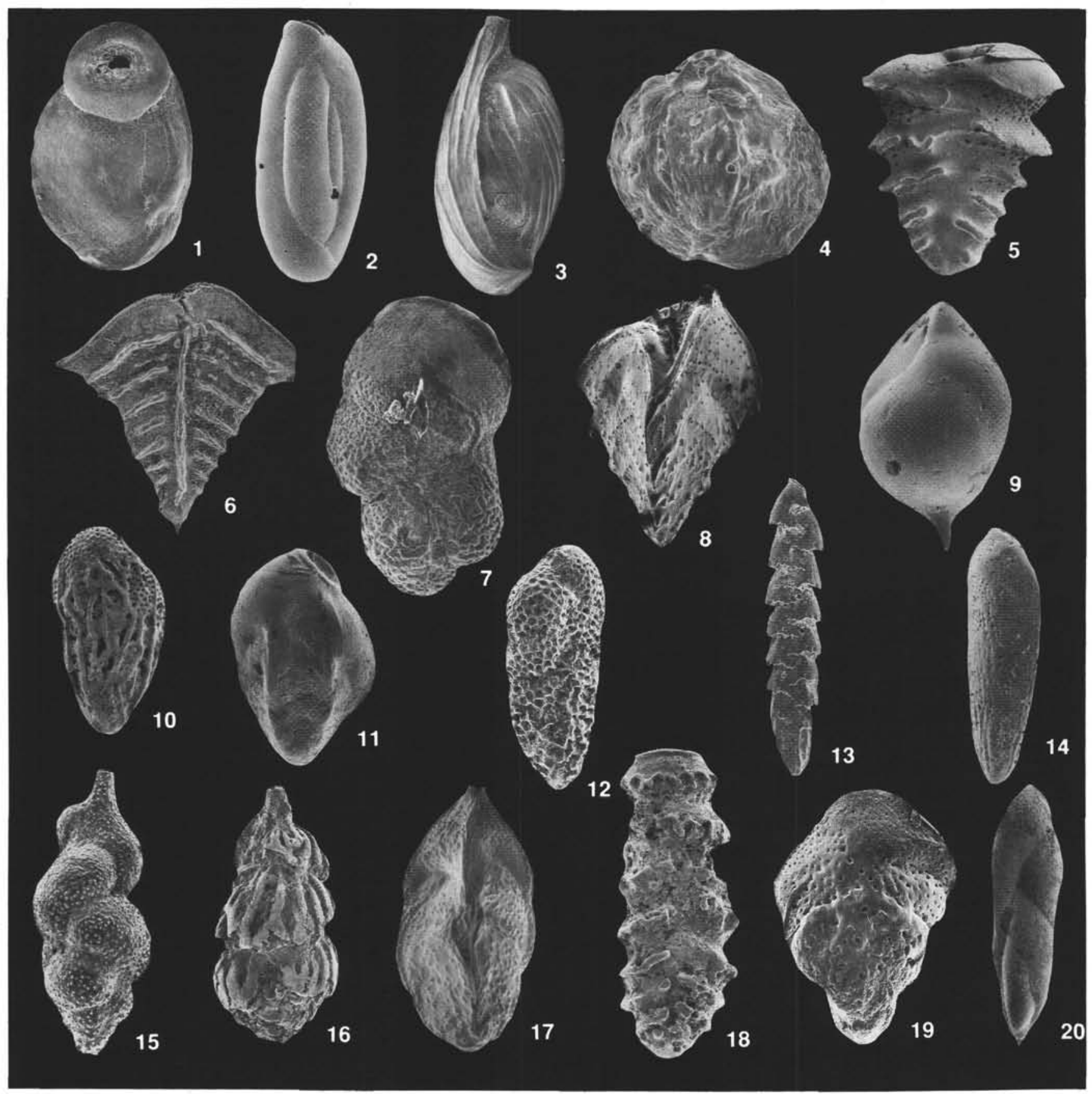

Plate 1. 1. Wiesnerella auriculata (Egger). Sample 133-821A-1H-1, 30-32 cm (124x). 2. Quinqueloculina oblonga (Montagu). Sample 133-821A-1H-1, 30-32 cm (124x). 3. Quinqueloculina poyeana carinata Albani. Sample 133-821 A-1H-1, 30-32 cm (100x). 4. Hauerina occidentalis Cushman. Sample 133-821A-1H-1, 30-32 cm (200x). 5. Patellinella carinata Collins. Sample 133-821A-1H-1, 30-32 cm (150x). 6. Bolivinella elegans Parr. Sample 133-821A-1H-1, 30-32 cm (128x). 7. Buliminella latissima Collins. Sample 133-821A-1H-1, 30-32 cm (200x). 8. Reussella simplex (Cushman). Sample 133-821A-29X-1, 74-76 cm (118x). 9. Buliminoides madagascariensis (d'O.) var. spicta (C. \& P.). Sample 133-821A-24X-1, 131-133 cm (150x). 10. Bolivina amygdalaeformis Brady. Sample 133-821A-24X-1, 131-133 cm (70x). 11. Bolivina subangularis Brady. Sample 133-821A-35X-1, 30-32 cm (70x). 12. Bolivina compacta Sidebottom, Sample 133-821A-35X-1,30-32 cm (100x). 13. Brizalina convallaria (Millett) Sample 133-821A-1H-1,30-32 $\mathrm{cm}(100 \times)$. 14. Brizalina striatula (Cushman). Sample 133-821A-24X-1, 131-133 cm (138x). 15. Siphouvigerina ampullacea (Brady). Sample 133-821A35X-1, 30-32 cm (150×). 16. Uvigerina porrecta (Brady). Sample 133-821A-24X-1, 131-133 cm (100x). 17. Trifarina bradyi Cushman. Sample 133-821A-1H-1, 30-32 cm (150x). 18. Bifarina fimbriata (Millett). Sample 133-821A-35X-1, 30-32 cm (150x). 19. Sigmavirgulina tortuosa (Brady). Sample 133-821A-17X-3, 30-32 cm (118x). 20. Fursenkoina pauciloculata (Brady). Sample 133-821A-1H-1, 30-32 cm (106X). 


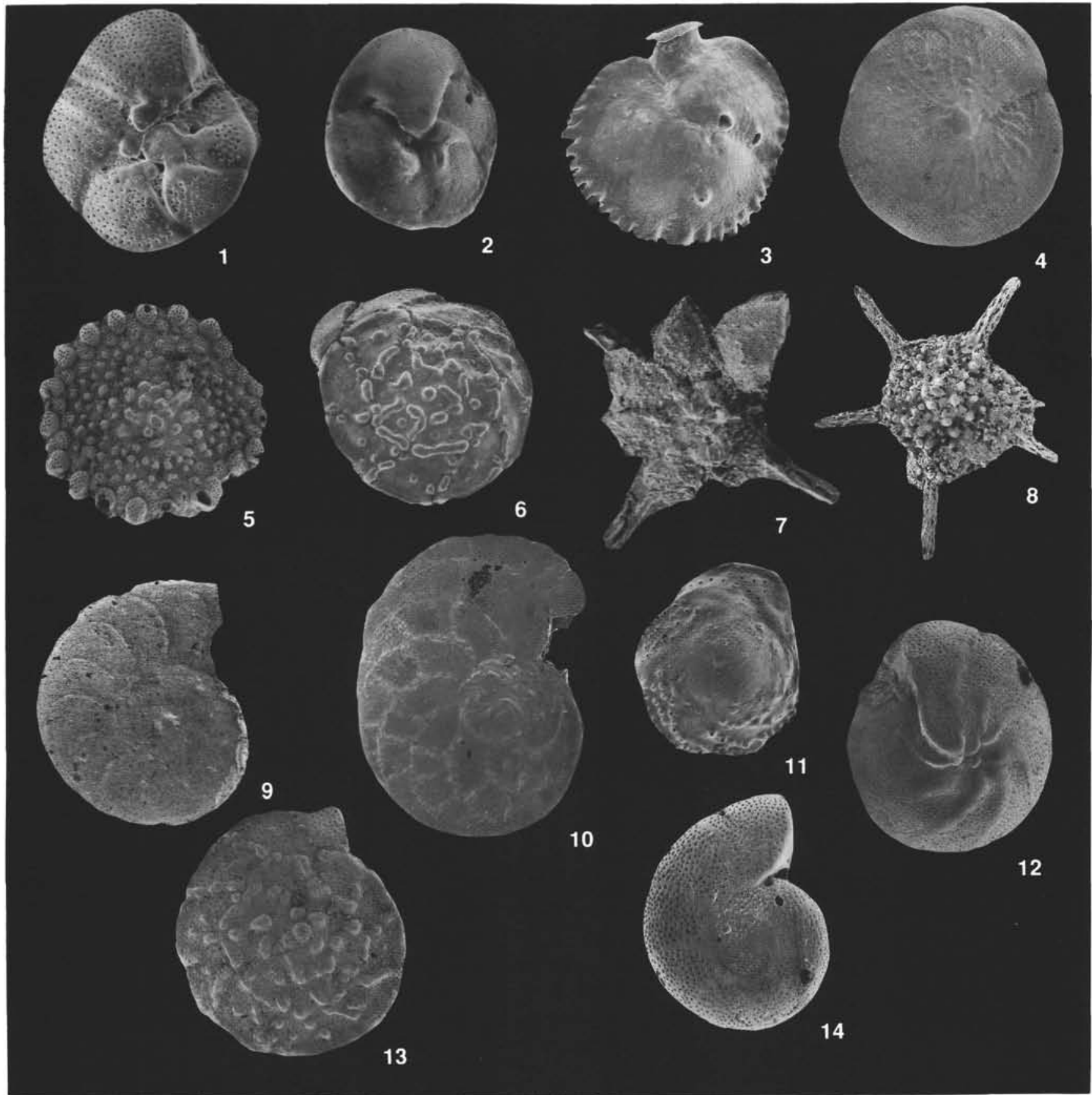

Plate 2. 1. Gavelinopsis cf. lobatulus (Parr). Sample 133-821A-1H-1, 30-32 cm (150x). 2. Neoeponides berthelotianus (d'Orbigny). Sample 133-821A29X-1, 74-76 cm (70x). 3. Siphonina tubulosa Cushman. Sample 133-821A-1H-1, 30-32 cm (100x). 4. Amphistegina papillosa Said. Sample 133-821A29X-1, 74-76 cm (30x). 5. Planorbulinella larvata (P. \& J.). Sample 133-821 A-29X-1, 74-76 cm (30x). 6. Asterorotalia gaimardii (d'Orbigny). Sample 133-821A-29X-1, 74-76 cm (45×). 7. Calcarina calcar d'Orbigny, young specimen. Sample 133-821A-1H-1, 30-32 cm (200x). 8. Calcarina spengleri (Gmelin). Sample 133-821A-2H-1, 30-32 cm (40X). 9. Operculina cf. ammonoides (Gronovius). Sample 133-821A-29X-1, 74-76 cm (62X). 10. Heterostegina depressa d'Orbigny. Sample 133-821A-2H-1, 30-32 cm (90x). 11. Svratkina tuberculata (B. \& W.). Sample 133-821A-35X-1, 30-32 cm (100x). 12. Heterolepa praecincta (Karrer). Sample 133-821A-29X-1, 74-76 cm (45x). 13. Heterolepa margaritifera (Brady). Sample 133-821A-29X-1, 74-76 cm (45x). 14. Anomalina glabrata Cushman. Sample 133-821 A-35X-1, 30-32 cm (150x). 